\title{
Front Matter: Volume 6854
}

, "Front Matter: Volume 6854," Proc. SPIE 6854, Optical Interactions with Tissue and Cells XIX, 685401 (12 March 2008); doi: 10.1117/12.791305

SPIE. Event: SPIE BiOS, 2008, San Jose, California, United States 


\section{PROGRESS IN BIOMEDICAL OPTICS AND IMAGING}

Vol. 9, No. 13

\section{Optical Interactions with Tissue and Cells XIX}

Steven L. Jacques

William P. Roach

Robert J. Thomas

Editors

21-23 January 2008

San Jose, California, USA

Sponsored and Published by

SPIE

Volume 6854

Proceedings of SPIE, 1605-7422, v. 6854

SPIE is an international society advancing an interdisciplinary approach to the science and application of light. 
The papers included in this volume were part of the technical conference cited on the cover and title page. Papers were selected and subject to review by the editors and conference program committee. Some conference presentations may not be available for publication. The papers published in these proceedings reflect the work and thoughts of the authors and are published herein as submitted. The publisher is not responsible for the validity of the information or for any outcomes resulting from reliance thereon.

Please use the following format to cite material from this book:

Author(s), "Title of Paper," in Optical Interactions with Tissue and Cells XIX, edited by

Steven L. Jacques, William P. Roach, Robert J. Thomas, Proceedings of SPIE Vol. 6854 (SPIE, Bellingham, WA, 2008) Article CID Number.

ISSN 1605-7422

ISBN 9780819470294

Published by

SPIE

P.O. Box 10, Bellingham, Washington 98227-0010 USA

Telephone +1 3606763290 (Pacific Time) · Fax +1 3606471445

SPIE.org

Copyright (C) 2008, Society of Photo-Optical Instrumentation Engineers.

Copying of material in this book for internal or personal use, or for the internal or personal use of specific clients, beyond the fair use provisions granted by the U.S. Copyright Law is authorized by SPIE subject to payment of copying fees. The Transactional Reporting Service base fee for this volume is $\$ 18.00$ per article (or portion thereof), which should be paid directly to the Copyright Clearance Center (CCC), 222 Rosewood Drive, Danvers, MA 01923. Payment may also be made electronically through CCC Online at copyright.com. Other copying for republication, resale, advertising or promotion, or any form of systematic or multiple reproduction of any material in this book is prohibited except with permission in writing from the publisher. The CCC fee code is 1605 $7422 / 08 / \$ 18.00$.

Printed in the United States of America.

Publication of record for individual papers is online in the SPIE Digital Library.

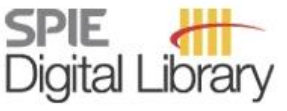

SPIEDigitallibrary.org

Paper Numbering: Proceedings of SPIE follow an e-First publication model, with papers published first online and then in print and on CD-ROM. Papers are published as they are submitted and meet publication criteria. A unique, consistent, permanent citation identifier (CID) number is assigned to each article at the time of the first publication. Utilization of CIDs allows articles to be fully citable as soon they are published online, and connects the same identifier to all online, print, and electronic versions of the publication. SPIE uses a six-digit CID article numbering system in which:

- The first four digits correspond to the SPIE volume number.

- The last two digits indicate publication order within the volume using a Base 36 numbering system employing both numerals and letters. These two-number sets start with $00,01,02,03,04$, 05, 06, 07, 08, 09, OA, OB ... 0Z, followed by 10-1Z, 20-2Z, etc.

The CID number appears on each page of the manuscript. The complete citation is used on the first page, and an abbreviated version on subsequent pages. Numbers in the index correspond to the last two digits of the six-digit CID number. 


\section{Contents}

ix Conference Committee

\section{SESSION 1 PHOTO-THERMAL INTERACTION}

685403 Use of optical reporter genes to assess sublethal cellular damage following skin ablation [6854-02]

G. J. Wilmink, S. R. Opalenik, Vanderbilt Univ. (USA); J. M. Davidson, Vanderbilt Univ. (USA) and Department of Veterans Affairs Medical Ctr. (USA); E. D. Jansen, Vanderbilt Univ. (USA)

685404 Part II: Morphological analysis of embryonic development following femtosecond laser manipulation [6854-03]

V. Kohli, A. Y. Elezzabi, Univ. of Alberta (Canada)

$685405 \quad$ NIR-laser tissue welding in an in vivo guinea pig animal model [6854-04]

V. Sriramoju, City College of New York (USA); H. E. Savage, New York Eye and Ear Infirmary (USA); A. Katz, R. Chakraverty, Y. Budansky, R. Podder, N. Davatgarzadeh, U. Kartazayev,

City College of New York (USA); R. B. Rosen, New York Eye and Ear Infirmary (USA);

R. R. Alfano, City College of New York (USA)

685406 Porcine skin ED50 damage thresholds for 1214 nm laser irradiation [6854-05]

B. Chen, The Univ. of Texas at Austin (USA); J. Oliver, Air Force Research Lab. (USA);

R. Vincelette, G. Pocock, R. Zaman, A. J. Welch, The Univ. of Texas at Austin (USA)

685408 The potential application of hairless guinea pigs as a replacement for the Yucatan mini-pig in animal studies [6854-07]

N. M. Jindra, Air Force Research Lab. (USA); M. L. Imholte, Northrop Grumman (USA)

685409 Air leak seal for lung dissection plane with diode laser irradiation: monitoring heatdenature with auto-fluorescence [6854-08]

M. Gotoh, T. Arai, Keio Univ. (Japan)

\section{SESSION 2 NEURAL STIMULATION}

6854 OB Frontiers in optical stimulation of neural tissues: past, present, and future (Invited Paper) [6854-10]

J. Wells, M. Bendett, J. Webb, Aculight Corp. (USA); C. Richter, A. Izzo, Northwestern Univ. (USA); E. D. Jansen, A. Mahadevan-Jansen, Vanderbilt Univ. (USA)

$6854 \mathrm{OC}$ Laser stimulation of the auditory system at $1.94 \mu \mathrm{m}$ and microsecond pulse durations [6854-11]

A. D. Izzo, J. T. Walsh, Jr., Northwestern Univ. (USA); H. Ralph, Northstar Neuroscience (USA);

J. Webb, J. Wells, M. Bendett, Aculight Corp. (USA); C.-P. Richter, Northwestern Univ. (USA) 
$6854 \mathrm{OE}$ Photostimulation of sensory neurons of the rat vagus nerve [6854-13]

A. Y. Rhee, Univ. of Maryland Biotechnology Institute (USA) and Univ. of Maryland, Baltimore (USA); G. Li, Univ. of Maryland Biotechnology Institute (USA) and Univ. of Maryland School of Dentistry (USA); J. Wells, Aculight Corp. (USA); J. P. Y. Kao, Univ. of Maryland Biotechnology Institute (USA), Univ. of Maryland, Baltimore (USA), and Univ. of Maryland School of Medicine (USA)

$6854 \mathrm{OF}$ Characterization of single auditory nerve fibers in response to laser stimulation [6854-14] P. Littlefield, A. D. Izzo, J. Mundi, J. T. Walsh, Jr., Northwestern Univ. (USA); E. D. Jansen, Vanderbilt Univ. (USA); M. Bendett, J. Webb, H. Ralph, Aculight Corp. (USA); C.-P. Richter, Northwestern Univ. (USA)

$6854 \mathrm{OH}$ Prosthetic systems for therapeutic optical activation and silencing of genetically targeted neurons [6854-16]

J. G. Bernstein, X. Han, M. A. Henninger, E. Y. Ko, X. Qian, G. Talei Franzesi, J. P. McConnell, P. Stern, R. Desimone, E. S. Boyden, Massachusetts Institute of Technology (USA)

6854 Ol Optical stimulation of excised murine sciatic nerve using 1.8-um wavelength laser [6854-17]

R. Cargill, T. Baumann, S. L. Jacques, Oregon Health \& Science Univ. (USA)

\section{SESSION 3 CELL BIOLOGY AND PHOTOCHEMISTRY}

$6854 \mathrm{OL}$ The EGFR family of receptors sensitizes cancer cells toward UV light [6854-20]

S. Petersen, Aalborg Univ. (Denmark) and SUNY at Buffalo (USA); M. T. Neves-Petersen, Aalborg Univ. (Denmark); B. Olsen, Univ. of Southern Denmark (Denmark)

6854 OM The mechanism of PDT-induced electrical blockade: the measurement of intracellular $\mathrm{Ca}^{2+}$ concentration changes in cardiac myocytes [6854-21]

A. Ito, S. Hosokawa, S. Hakomori, Keio Univ. (Japan); S. Miyoshi, K. Soejima, Keio Univ. School of Medicine (Japan); T. Arai, Keio Univ. (Japan)

$6854 \mathrm{ON}$ Inactivation of viruses with a femtosecond laser via impulsive stimulated Raman scattering [6854-22]

K. T. Tsen, Arizona State Univ. (USA); S.-W. D. Tsen, C.-L. Chang, C.-F. Hung, T.-C. Wu, Johns Hopkins Univ. School of Medicine (USA); B. Ramakrishna, K. Mossman, Arizona State Univ. (USA); J. G. Kiang, Uniformed Services Univ. of the Health Sciences (USA)

685400 Investigation of reactive oxygen species formation in living cells during femtosecond laser based cell surgery [6854-23]

J. Baumgart, Laser Zentrum Hannover e.V. (Germany); W. Bintig, A. Ngezahayo, Leibniz Univ. (Germany); W. Ertmer, Univ. of Hannover (Germany); H. Lubatschowski,

A. Heisterkamp, Laser Zentrum Hannover e.V. (Germany)

$6854 \mathrm{OQ}$ The vascular response observation by the monitoring of the photosensitizer, oxygen, and blood flow during the high intensity pulsed excitation photodynamic therapy $\mathrm{lh}$ after water-soluble photosensitizer intravenous injection [6854-25]

S. Hakomori, H. Matsuo, T. Arai, Keio Univ. (Japan) 
6854 OT Modeling tissue optics using Monte Carlo modeling: a tutorial (Invited Paper) [6854-28]

S. L. Jacques, Oregon Health \& Science Univ. (USA)

6854 OU Modeling the interaction of lasers and tissue: importance of accounting for time varying electric properties [6854-29]

D. J. Evans, M. L. Manwaring, Univ. of Idaho (USA)

$6854 \mathrm{OV}$ Incorporation of refractive index gradients in the solution of the radiative transport equation [6854-30]

J. J. Zohner, Air Force Research Lab. (USA); C. D. Clark, Northrop Grumman (USA); T. Kahn,

B. C. McAdoo, Clemson Univ. (USA); R. J. Thomas, Air Force Research Lab. (USA)

6854 OW Spectral analysis of Pennes' bio-heat equation [6854-31]

L. X. Cundin, Conceptual MindWorks, Inc./Air Force Research Lab. (USA)

6854 OX Modeling explosive cellular damage [6854-33]

D. G. Mixon, Air Force Research Lab. (USA)

$6854 \mathrm{OZ}$ Comparing finite difference time domain and Monte Carlo modeling of human skin interaction with terahertz radiation [6854-36]

B. L. Ibey, J. A. Payne, D. G. Mixon, R. J. Thomas, W. P. Roach, Air Force Research Lab. (USA)

\section{SESSION 5 PHOTO-THERMAL ABLATION}

685410 Pressure (mechanical) effects in infrared tissue ablation (Invited Paper) [6854-37]

G. Edwards, W. Wagner, A. Sokolow, Duke Univ. (USA); R. Pearlstein, Duke Univ. Medical Ctr. (USA)

685411 Viability evaluation of culture cells patterned by femtosecond laser-induced impulsive force [6854-38]

N. Takizawa, Hamano Life Science Research Foundation (Japan); K. Okano, Hamano Life Science Research Foundation (Japan) and Osaka Univ. (Japan); T. Uwada, Hamano Life Science Research Foundation (Japan); Y. Hosokawa, H. Masuhara, Hamano Life Science Research Foundation (Japan), Osaka Univ. (Japan), and CREST, Japan Science and Technology Agency (Japan)

685412 Threshold parameters of the mechanisms of selective nanophotothermolysis with gold nanoparticles [6854-39]

V. Pustovalov, Belarusian Institute of System Analysis (Belarus); V. Zharov, Univ. of Arkansas for Medical Sciences (USA)

685413 Part I. Embryonic surgery using femtosecond laser pulses for the delivery of exogenous materials and the analysis of gene expression [6854-40]

V. Kohli, A. Y. Elezzabi, Univ. of Alberta (Canada) 
685414 Smart bombing a single targeted cell with femtogram order reagents using laser-induced shockwave technique [6854-41]

K. Okano, Hamano Life Science Research Foundation (Japan) and Osaka Univ. (Japan);

N. Takizawa, T. Uwada, Hamano Life Science Research Foundation (Japan); Y. Hosokawa, H. Masuhara, Hamano Life Science Research Foundation (Japan), Osaka Univ. (Japan), and CREST, Japan Science and Technology Agency (Japan)

685415 An in vitro corneal model with a laser damage threshold at $2 \boldsymbol{\mu m}$ that is similar to that in the rabbit [6854-42]

M. S. Foltz, M. L. Denton, K. J. Schuster, Northrop Grumman (USA); L. E. Estlack, Conceptual Mindworks, Inc. (USA); S. S. Kumru, Air Force Research Lab. (USA)

$685416 \quad$ Ultra-short pulsed laser tissue ablation using focused laser beam [6854-44]

M. K. Jaunich, S. Raje, K. Mitra, M. S. Grace, Florida Institute of Technology (USA); M. Fahey, G. Spooner, Raydiance, Inc. (USA)

685417 Laser ablation of otic capsule tissue [6854-45]

R. G. McCaughey, B. J. F. Wong, Beckman Laser Institute (USA); J. Tafoya, Y. Sun, Infralase Inc. (USA); R. Jain, Univ. of New Mexico (USA)

685418 Selective removal of cholesterol ester in atherosclerotic plaque using nanosecond pulsed laser at $5.75 \mu \mathrm{m}[6854-46]$

K. Ishii, H. Tsukimoto, H. Hazama, K. Awazu, Osaka Univ. (Japan)

\section{SESSION 6 SPECTROSCOPY, OPTICS, AND SCATTERING}

685419 Optimizing the use of laser alignment thermal sensitive paper for a 1.54 micron Er-glass laser [6854-47]

K. J. Walter, T. E. Eurell, T. E. Johnson, Colorado State Univ. (USA)

6854 1A Coherent backscattering of polarized light for tissue diagnostics: an electric field Monte Carlo study [6854-48]

M. XU, Fairfield Univ. (USA)

6854 1C Optical properties of human tendons characterized by PSOCT and their relation to tendinopathy: a clinical study [6854-51]

P. O. Bagnaninchi, Keele Univ. (United Kingdom); D. Churmakov, M. Bonesi, Cranfield Health, Cranfield Univ. (United Kingdom); Y. Yang, Keele Univ. (United Kingdom); C. Phelan, Univ. Hospital of North Staffordshire (United Kingdom); N. Maffulli, Keele Univ. (United Kingdom); I. Meglinski, Cranfield Health, Cranfield Univ. (United Kingdom); A. El Haj, Keele Univ. (United Kingdom)

6854 1D Optical imaging of structures within highly scattering material using a lens and aperture to form a spatiofrequency filter [6854-52]

N. Pfeiffer, P. Chan, G. H. Chapman, F. Vasefi, B. Kaminska, Simon Fraser Univ. (Canada)

$6854 \mathrm{IE}$ Enhanced angular domain optical imaging by background scattered light subtraction from a deviated laser source [6854-53]

F. Vasefi, G. H. Chapman, P. Chan, B. Kaminska, N. Pfeiffer, Simon Fraser Univ. (Canada) 
6854 IF Enhancement of light in tissue using hyper-osmotic agents [6854-54]

R. T. Zaman, B. Chen, A. B. Parthasarathy, A. D. Estrada, Jr., A. Ponticorvo, H. G. Rylander III, A. K. Dunn, A. J. Welch, The Univ. of Texas at Austin (USA)

$6854 \mathrm{1H}$ Characterization of neutral density filters for use in near infrared lasers [6854-56]

E. Rickers, K. J. Walter, T. E. Johnson, Colorado State Univ. (USA)

POSTER SESSION

$68541 \mathrm{~J} \mathrm{Morphometric} \mathrm{effects} \mathrm{of} \mathrm{different} \mathrm{energy} \mathrm{densities} \mathrm{of} \mathrm{diode} \mathrm{laser} \mathrm{on} \mathrm{adipose} \mathrm{tissue} \mathrm{in} \mathrm{rats}$ [6854-59]

H. C. Senhorinho, G. L. Bichinho, P. Nohama, M. A. Gariba, Pontifical Catholic Univ. of Paraná (Brazil)

$68541 \mathrm{~K}$ Femtosecond laser manipulation techniques for individual patterning of biological microobject [6854-60]

Y. Hosokawa, Hamano Life Science Research Foundation (Japan), Osaka Univ. (Japan), and CREST, Japan Science and Technology Agency (Japan); Y. Jiang, Hamano Life Science Research Foundation (Japan) and Handai Nano Photonics Institute (Japan); I. Oh, Handai Nano Photonics Institute (Japan) and Osaka Univ. (Japan); N. Takizawa, T. Uwada, Hamano Life Science Research Foundation (Japan); K. Okano, Hamano Life Science Research Foundation (Japan) and Osaka Univ. (Japan); H. Masuhara, Hamano Life Science Research Foundation (Japan), Handai Nano Photonics Institute (Japan), Osaka Univ. (Japan), and CREST, Japan Science and Technology Agency (Japan)

$6854 \mathrm{lL} \quad$ Femtosecond cellular transfection using a non-diffracting beam [6854-61]

X. Tsampoula, V. Garcés-Chávez, M. Comrie, D. J. Stevenson, B. Agate, C. T. A. Brown, F. Gunn-Moore, K. Dholakia, Univ. of St. Andrews (United Kingdom)

$68541 \mathrm{M}$ Full path Monte Carlo simulation of fluorescence in non-voxelized complex heterogeneous mouse model [6854-62]

J.-F. Delorme, G. Ma, Advanced Research Technologies (Canada); F. Lesage, Ecole Polytechnique de Montreal (Canada); F. Leblond, A. Benyamin-Seyar, Advanced

Research Technologies (Canada)

Author Index 
Downloaded From: https://www.spiedigitallibrary.org/conference-proceedings-of-spie on 26 Apr 2023

Terms of Use: https://www.spiedigitallibrary.org/terms-of-use 


\title{
Conference Committee
}

\author{
Symposium Chairs \\ James Fujimoto, Massachusetts Institute of Technology (USA) \\ R. Rox Anderson, Wellman Center for Photomedicine, Massachusetts \\ General Hospital (USA), and Harvard School of Medicine (USA)
}

Program Track Chairs

Steven L. Jacques, Oregon Health and Science University (USA)

William P. Roach, Air Force Research Laboratory (USA)

Conference Chairs

Steven L. Jacques, Oregon Health \& Science University (USA)

William P. Roach, Air Force Research Laboratory (USA)

Robert J. Thomas, Air Force Research Laboratory (USA)

Program Committee

Randolph D. Glickman, The University of Texas Health Science Center at San Antonio (USA)

E. Duco Jansen, Vanderbilt University (USA)

Anita Mahadevan-Jansen, Vanderbilt University (USA)

Jill McQuade, Air Force Research Laboratory (USA)

Jessica C. Ramella-Roman, The Catholic University of America (USA)

Alfred Vogel, Universität zu Lübeck (Germany)

Lihong V. Wang, Washington University in St. Louis (USA)

\section{Session Chairs}

1 Photo-Thermal Interaction

E. Duco Jansen, Vanderbilt University (USA)

2 Neural Stimulation

Anita Mahadevan-Jansen, Vanderbilt University (USA)

3 Cell Biology and Photochemistry

Randolph D. Glickman, The University of Texas Health Science Center at San Antonio (USA)

$4 \quad$ Modeling and Computation

Robert J. Thomas, Air Force Research Laboratory (USA) 
5 Photo-Thermal Ablation

Robert J. Thomas, Air Force Research Laboratory (USA)

6 Spectroscopy, Optics, and Scattering

Lihong V. Wang, Washington University in St. Louis (USA)

Jessica C. Ramella-Roman, The Catholic University of America (USA)

Poster Session

Robert J. Thomas, Air Force Research Laboratory (USA) 